\title{
Amphibia, Anura, Hylidae, Hypsiboas buriti (Caramaschi and Cruz, 1999): Distribution update and map
}

\author{
Letícia Regina A. Braga ${ }^{1,2}$, Reuber A. Brandão ${ }^{1^{*}}$ and Guarino R. Colli ${ }^{2}$ \\ 1 Universidade de Brasília, Departamento de Engenharia Florestal, Laboratório de Fauna e Unidades de Conservação. CEP 70910-900. Brasília, DF, \\ Brazil. \\ 2 Universidade de Brasília, Instituto de Ciências Biológicas. CEP 70910-900. Brasília, DF, Brazil. \\ * Corresponding author. E-mail: reuberbrandao@yahoo.com.br
}

ABSTRACT: We present a new locality record for Hypsiboas buriti, and review the previous records. The species is found associated to permanent ponds at open physiognomies on the top of high plateaus (over $900 \mathrm{~m}$ a.s.l.) in Central Brazil.

The Hypsiboas pulchella group, previously known as Hyla pulchella group, includes the species of the Hypsiboas polytaenius clade: Hypsiboas beckeri (Caramaschi and Cruz 2004); H. botumirim Caramaschi, Cruz and Nascimento 2009; H. buriti (Caramaschi and Cruz 1999); H. cipoensis (Lutz 1968); H. goianus (Lutz 1968); H. latistriatus (Caramaschi and Cruz 2004); H. leptolineatus (Braun and Braun 1977); H. phaeopleura (Caramaschi and Cruz 2000); H. polytaenius (Cope 1870); and H. stenocephalus (Caramaschi and Cruz 1999). The most evident characteristic of this clade is the conspicuous color pattern, composed by longitudinal stripes (Eterovick et al. 2002; Faivovich et al. 2005). Due this characteristic color pattern, the species in the group of $H$. polytaenius are commonly known as "pajamas treefrogs" (see Eterovick and Sazima 2004).

Hypsiboas buriti (Figure 1) was described based on two individuals captured at Fazenda São Miguel, Buritis municipality, state of Minas Gerais, Brazil. The individuals used as types were part of a series of eight males collected by R.A.B at the type-locality, at February 1993. Six specimens were deposited in Coleção Herpetológica da Universidade de Brasília (CHUNB), housed at Universidade de Brasília, Brasília, Distrito Federal, Brazil, whereas other two individuals were sent to Museu Nacional (MNRJ), Rio de Janeiro, Brazil.

Data on Hypsiboas buriti distribution is very scarce. This species is known from the type locality (Buritis municipality, state of Minas Gerais) and Distrito Federal (Frost 2008). Brandão and Araujo (2001) reports H. buriti using grasslands in Brasília, but didn't present information about the place of record. Although the species were recorded for Distrito Federal (Brandão and Araujo 2001), Caramaschi et al. (2009) considered the species restricted to the type-locality. The species type-locality coordinates presented by Caramaschi and Cruz (1999), and used by Frost (2008) and Caramaschi et al. (2009) refers to the city of Buritis, located at $500 \mathrm{~m}$ above sea level (i.e. a lowland area). However, the correct place where $H$. buriti types were collected is located on the top of a large plateau, at $940 \mathrm{~m}$ above sea level (Figure 2). The coordinates of the exact place where the species was originally collected are presented in the Table 1.

Herein, we update information on geographical records of $H$. buriti, clarifying some localities and presenting a new record for Paracatu municipality, state of Minas Gerais (Figure 2). At Paracatu municipality, the individuals were found calling in small scrubs near a small permanent pond, in a campo limpo vegetation, a typical Cerrado physiognomy, characterized by grasses associated to hydromorphic soils seasonally flooded.

At Fazenda Água Limpa, Brasília, the individuals were found close a permanent pond with $15 \mathrm{~m}^{2}$ total area, and $2 \mathrm{~m}$ of maximum depth, formed by the damming of a small creek. The plant cover of this pond is mainly composed by invasive or opportunistic plants, as Pteridum sp., Tibouchina sp., Trembleya sp., and other Melastomatacea plants. The individuals call from several kinds of perches,

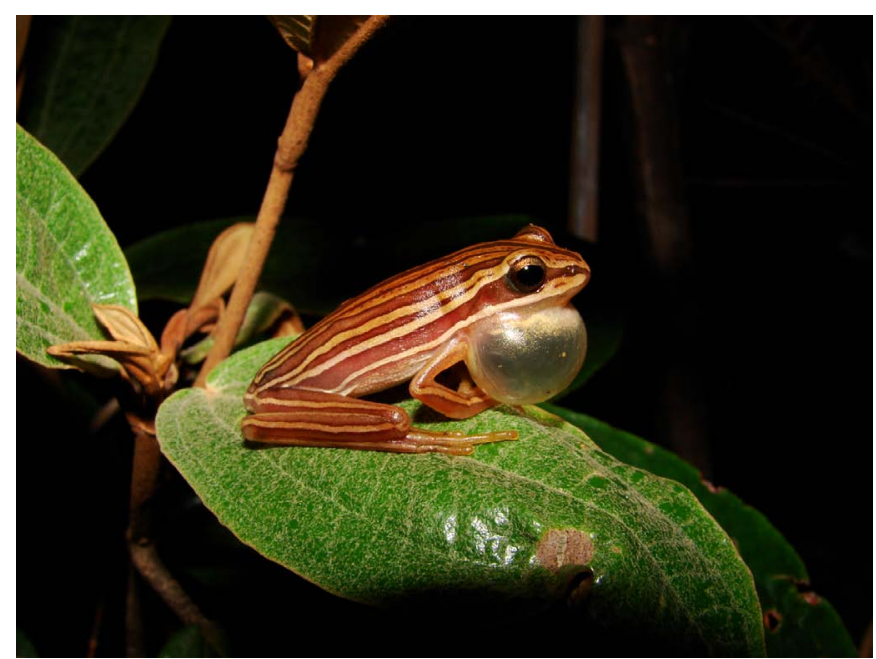

Figure 1. Adult male of Hypsiboas buriti (Caramaschi and Cruz 1999), Fazenda Água Limpa, Brasília. Photo: Reuber Brandão. 
TABLE 1. Locality data of Hypsiboas buriti records.

\begin{tabular}{|l|c|c|c|c|}
\hline LOCALITY & MUNICIPALITY & LATITUdE (S) & LONGITUDE (W) & ALTITUDE (M) \\
\hline Fazenda Água Limpa & Brasília - DF & $15^{\circ} 58^{\prime} 13.3^{\prime \prime}$ & $47^{\circ} 55^{\prime} 59.7^{\prime}{ }^{\prime}$ & 1175 \\
\hline Fazenda Champion & Paracatu - MG & $17^{\circ} 29^{\prime} 20.4^{\prime \prime}$ & $47^{\circ} 19^{\prime} 45.5^{\prime}{ }^{\prime \prime}$ & 930 \\
\hline Fazenda São Miguel & Buritis - MG & $16^{\circ} 04^{\prime} 07^{\prime \prime}$ & $46^{\circ} 36^{\prime} 40.2^{\prime \prime}$ & 940 \\
\hline
\end{tabular}

like grasses, stems, and large leafs. We found males calling from soil up to $2 \mathrm{~m}$ high. This area is characteristic of campo sujo physiognomy, a kind of Cerrado vegetation dominated by grasses and scattered bushes. We also found few individuals calling in two temporary ponds, formed by the accumulation of rain water near to an off road.

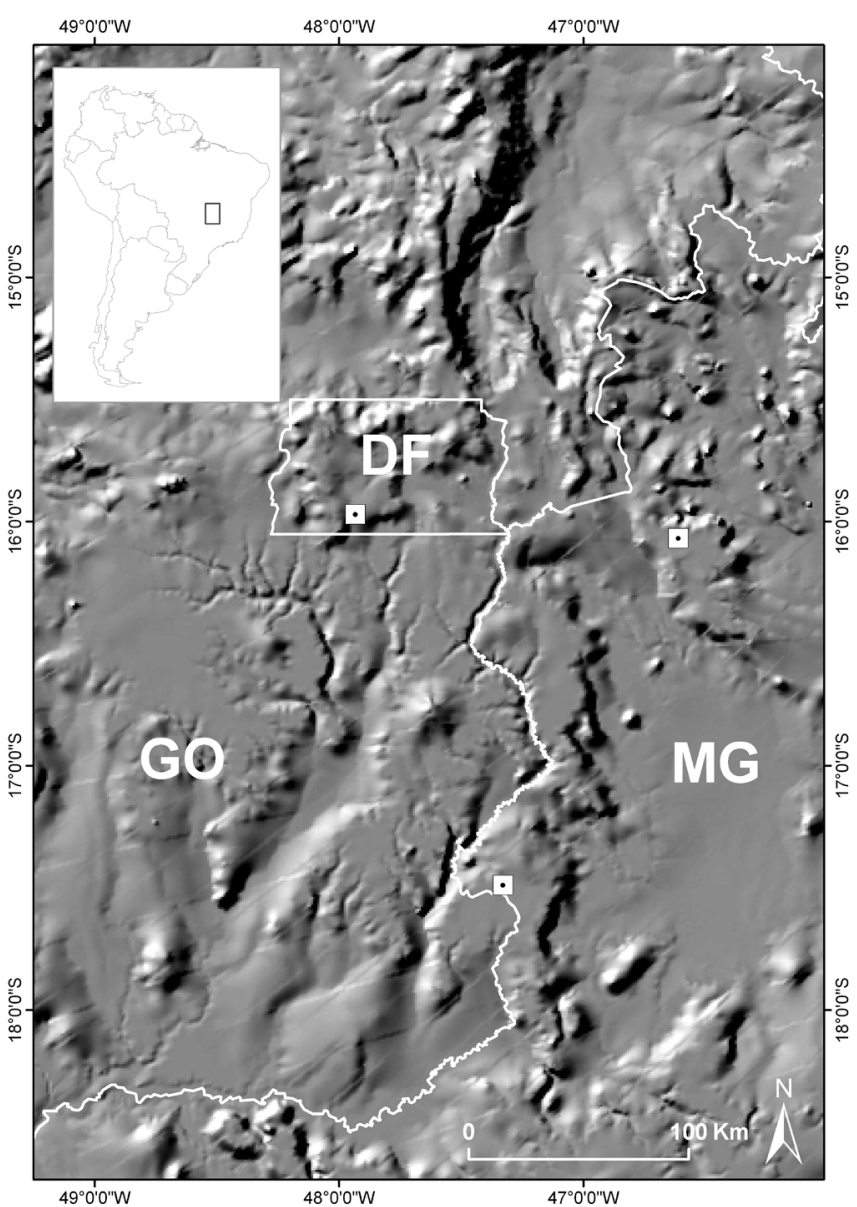

FIGURE 2. Distribution map of Hypsiboas buriti (dot center square) in Distrito Federal (DF) and state of Minas Gerais (MG). The magnifying region corresponds to the square in the South American inset map (GO: state of Goiás).
In Buritis municipality, all individuals were found calling in herbaceous plants, in campo limpo (grasslands) vegetation. All individuals were sampled in the margins of a small reservoir formed by damming a small Vereda rivulet.

All records of Hypsiboas buritiarelocated on the Planalto Central, over $900 \mathrm{~m}$ above sea level, were the species uses small permanent ponds in grasslands for breed. Due to its deep mud soils and plain relief, the Planalto Central highlands are quickly converted in agricultural lands, especially for irrigated monoculture crops, as soybean, coffee, cotton and corn. No known populations of $\mathrm{H}$. buriti are located inside protected areas.

ACKNOWLEDGMENTS: The authors are grateful to Renata Françoso for the distribution map; to FINATEC (Edital 08/2009) for the financial support, and to Fazenda Água Limpa, Universidade de Brasília, for the permission to work in the area.

\section{LITERATURE CiTED}

Brandão, R.A. and A.F.B Araújo. 2001. A herpetofauna associada às matas de galeria no Distrito Federal; p. 560-604 In: Ribeiro, J.F., C.E.L Fonseca and J.C. Sousa-Silva (ed.). Cerrado: Caracterização e Recuperação de Matas de Galeria. Planaltina: Embrapa-CPAC.

Caramaschi, U. and C.A.G. Cruz. 1999. Duas espécies novas do grupo de Hyla polytaenia Cope, 1870 do Estado de Minas Gerais, Brasil (Amphibia, Anura, Hylidae). Boletim do Museu Nacional, Série Zoologia, Rio de Janeiro 403: 1-10.

Caramaschi, U., C.A.G.Cruz and D. Silvano. 2009. Hypsiboas buriti In: IUCN 2009. IUCN Red List of Threatened Species. Version 2009.2. Available at <www.iucnredlist.org $>$. Downloaded on 22 December 2009.

Eterovick, P.C., I.S. Barros and I. Sazima. 2002. Tadpoles of two species in the Hyla polytaenia species group and comparison with other tadpoles of Hyla polytaenia and Hyla pulchella groups (Anura, Hylidae). Journal of Herpetology 36(3): 512-515.

Eterovick, P.C. and I. Sazima. 2004. Anfíbios da Serra do Cipó, Minas Gerais, Brasil. Editora PUC Minas, Belo Horizonte, 152p.

Faivovich, J., C.F.B. Haddad, P.C.A. Garcia, D.R. Frost, J.A. Campbell and W.C. Wheeler. 2005. Systematic review of the frog family Hylidae, with special reference to Hylinae: Phylogenetic analysis and taxonomic revision. Bulletin of the American Museum of Natural History 294: $1-240$.

Frost, D.R. 2008. Amphibian Species of the World: an Online Reference. Version 5.3 (12 February, 2009). Electronic Database accessible at $<$ http://research.amnh.org/herpetology/amphibia>. Captured on 22 December 2009.

RECEIVED: February 2010

REVISED: Marh 2010

ACCEPTED: March 2010

Published ONLINE: May 2010

EDITORIAL RESPONSIBILITY: Victor G. Dill Orrico 